\title{
Co-ordination media in cross-national networks of small and medium-sized enterprises*
}

\author{
Ralph-Elmar Lungwitz, Peter Le, Sebastian Campagna**
}

Not only large corporations but also SMEs increasingly organise into crossborder networks, in order to benefit from the advantages of international division of labour. As regards the co-ordination of network activities it makes sense to distinguish between the role of social co-ordination media and the factual and temporal co-ordination of network activities. Social co-ordination media are geared to the generation of mutual "reliability". Their mode of operating is closely linked to the internal power structures of the networks.

Nicht nur Großunternehmen, sondern auch Kleine und Mittlere Unternehmen schließen sich in wachsendem Maße zu grenzüberschreitenden Netzwerken zusammen, um die Vorteile der internationalen Arbeitsteilung zu nutzen. Hinsichtlich der Koordinierung von Netzwerksaktivitäten macht es Sinn, zwischen dem Wirken sozialer Koordinierungsmedien und der sachlichzeitlichen Koordinierung von Teilaktivitäten zu unterscheiden. Die sozialen Koordinierungsmedien sind auf die wechselseitige Generierung von Verlässlichkeit (,,Relianz") ausgerichtet. Ihre Wirkungsweise hängt mit charakteristischen Machtstrukturen innerhalb der Netzwerke zusammen.

Key words: SMEs, Cross-border Networks, Co-ordination Media

* $\quad$ Manuscript received: 21.07.06, accepted: 26.09.06 (2 revisions)

** Ralph-Elmar Lungwitz, Dr., Director of the Institute of Economic and Social Studies Chemnitz. Main research areas: SMEs, networks, labour relations. Corresponding address: WISOC@t-online.de

Peter Le, Research Associate, University of Dortmund, Department of Economic and Industrial Sociology. Main research areas: Internationalisation of SMEs, knowledge management. Corresponding address: p.le@wiso.uni-dortmund.de

Sebastian Campagna, Research Associate, University of Dortmund, Department of Economic and Industrial Sociology. Main research areas: Internationalisation of SMEs, regional networks. Corresponding address: s.campagna@wiso.uni-dortmund.de 


\section{Cross-national networks of small and medium-sized enterprises in Europe- Facing new challenges}

The intensification of international market relations has entailed an increasing trend towards the cross-national organisation of the value-added processes of small and medium-sized enterprises (SMEs) in Europe too (EU Observatory of European SME; Enterprise Survey 2003/05; Kinkel/Lay/Maloca 2004). Especially for SMEs, the participation in international networks represents a chance to play an active part in the globalisation process despite restrictions due to their size as well as a chance to boost their competitiveness by opening up resources that would otherwise not have been accessible to them (HirschKreinsen/Wannöffel 2003; Eggers/Lay 2003).

A specific constellation of conditions pertains to international SME networks which include both West European enterprises and SME from Central and East European transformation countries. There is much empirical evidence that the use of the relatively cheap labour in the Central/East European neighbour countries represented a decisive motive for the transnational economic activity of the West European and, in particular the German, SME (Bluhm 2000, Kinkel et al, loc. cit.). Analyses of the German foreign trade with the Visegrad states showed that the growing trade volume during the 1990s was to a large extent realised with job processing (Angerer 2000). Especially labour-intensive subprocesses, which as a rule did not involve high qualification requirements, were assigned to Central/East European partner companies. Recently, however, several developments have emerged that increasingly erode the traditional basis of the co-operation and network relations of German SME with Central/East Europe.

a) If one equates the wage level of 1995 with 100, the nominal wages in the new EU states increased to the factor 251 (Schulten 2004). In Poland, for instance, the average monthly gross wages in the industrial sector rose from 1,233 PLN in 1998 to 2,290 PLN in 2004 (bfai 2005:40). This fact also underlines the general thesis that there is a trend towards the alignment of the per capita income in the integrated economic area (Brücker/Schrettl 1997). Of course, one cannot simply equate wage increases with a rise in labour costs, as an increase in productivity and the reduction of non-wage labour costs can develop a compensatory effect. Nonetheless, it is clear that this development puts pressure on the Central/East European SME to innovate and that it also affects the structural foundations of network relations with a West-East European component.

b) In addition to the trend towards higher wages and labour costs in Central/Eastern Europe, a general trend towards the upward revaluation of the Central/East European currencies in comparison to the euro also hampers a cooperation primarily aiming at cost effects. 
c) Moreover, the wage gaps between the new EU Member States on the one hand and countries such as the Ukraine, Moldova and the Republic of Belarus on the other hand are growing too. This creates an incentive for West European, in particular German, SME to review their economic relations with countries such as Poland, Hungary or the Czech Republic and to reorientate themselves towards these European low-wage countries.

Therefore, a structural change in the cross-national co-operation and network relations between enterprises from West Europe and their partners in the new EU states seems inevitable in the long run: In the future, these relations will not be based primarily on the utilisation of wage cost advantages but on the use of complementary competencies; wage cost advantages will, however, continue to constitute an additional promotive factor. With this development, the integration of the Central/East European enterprises into the transnational value chain increasingly sheds its transformation specifics and approaches the pattern existing within Western Europe.

Despite a downright boom of empirical and theoretical research on the question of networks, the practices and problems of the transnational co-ordination of SME-networks for the most part represent a blind spot. The debate about networks that took place in the context of the globalisation discourse (inter alia Bartlett/Ghoshal 1992; Sauer/Döhl 1994; v. Behr/Hirsch-Kreinsen 1998; Pries 1999) largely referred to global players and included both company branches and legally independent enterprises within the scope of supplier networks. This paper, however, refers to "pure" networks that only consist of small and medium-sized enterprises which constantly co-operate while maintaining their legal independence. This conceptual distinction seems to be essential to us, as the co-ordination of the network companies can in this case not be effected by means of the mobilisation of market resources specified by proprietary rights but instead special social co-ordination media are required to ensure the cohesion as well as the developability and the efficiency of the network. It makes sense to distinguish between two components regarding the co-ordination of network activities: For one thing, networks are based on the realisation of an interrelated overall process that is characterised by the division of labour. The actions of the individual network actors therefore have to be co-ordinated in such a way as regards content and timing, that the overall process can flow as smoothly as possible. For another thing, the social co- ordination media in a narrow sense have to be distinguished from the above-mentioned co-ordinating activities, as they are primarily geared towards generating reliability. This is a precondition for actors to engage in the potentially risky project of a network-like cooperation and to maintain it too. In this connection, Ortmann (2003) introduces the concept of "Relianz" (reliability) and defines it as "being able to count on" others. This reliability can be based on quite different sources, inter alia on information about the other companies' interests, on the ascription of certain 
personal characteristics or on the knowledge of the given power relations and the hence resulting action rationalities. The development and maintenance of security of action by means of "Relianz" (reliability) is the condition for the development and reproduction of the network and thus also for the factual and temporal co-ordination of the individual activities in the network.

\section{Methodological approach}

This article is based on findings that were made in the context of the research project „Koordination internationaler Netzwerke kleiner und mittlerer Unternehmen - KoNet" (Co-ordination of international networks of small and medium-sized enterprises) ${ }^{1}$. The examined networks span the economic area of the European Union, including the new Member States as well as other Eastern European countries. The main emphasis of the empiricism lay on the realisation of six qualitatively oriented case studies of international networks of SMEs. The survey period began in December 2002 and ended in November 2003. All in all, 29 guided interviews were conducted with a total of 33 persons. The interview partners were representatives of the management of the individual network enterprises and, if not identical, experts who were chiefly responsible for the cooperation relations between the companies. These case studies related to both network-like organised research and development processes (biotechnology, microsystems technology, electrotechnology) and to the manufacture of more traditional industrial products in the furniture, textile and music instrument industry. With respect to the motives, target regions and geographic scope of the internationalisation as well as to the frequency of co-operation with foreign partners according to co-operation fields, company size and sectors, the sample shows absolutely typical characteristics and trends of cross-national activities of SMEs (OECD 2002; Observatory of European SME loc.cit;; Kinkel et al. loc.cit.). Despite the considerable heterogeneity of the research sample, a number of common characteristics regarding the forms of social embedding and functional mechanisms became apparent, which can be regarded as specific to SME-networks and whose existence was also confirmed by other research (Lungwitz/Preusche 2002) on transnational activities of SMEs. These inter alia include:

1. The significant role of specific individuals regarding the development and the practical functioning of networks;

2. The companies' scarcity of resources;

1 The research project was conducted at the Chair of Economic and Industrial Sociology of the University of Dortmund from March 2002 to November 2004 and was sponsored by the Volkswagen Foundation in the context of its grant initiative "Global Structures and their Governance". 
3. The considerable role played by personal and institutional support networks;

4. The differentiated internal power structure of the network.

It was our central concern to clarify on the basis of the case studies how "reliability" develops and is maintained, which role especially power plays as a social co-ordination medium and of what significance individuals are for the process. In doing so, we occasionally also address the importance of "reliability" for the co-ordination of the content and timing of individual actions.

Furthermore, we have deliberately included both cases with an East-West dimension, that are influenced by economo-political transformation processes, as well as networks in which solely SME from established West European market economies co-operate. In doing so, we proceed on the assumption that networks which primarily aim at making use of wage cost advantages in Central/East European countries also differ from networks that are based on the use of complementary competencies (as characteristic for Western Europe) regarding the safeguarding of reliability in networks. The qualitative orientation of the research project opens up the possibility of revealing entrepreneurial action in its interpretive and intentional contexts and thus of reconstructing a dimension of the process one would not have been able to understand with the aggregated data alone.

\section{Co-ordination media and the specific characteristics of SME- networks - Results and discussions}

The SME-networks examined in the project are undoubtedly very heterogeneous. These differences already begin with respect to the temporal dimension: Two of the networks concern long-term production networks with a specific East-West component, the basis of the other two networks are jointly implemented projects of product development, they were therefore conceived as temporary collaborations from the start. Moreover, the networks markedly differ as regards the differently organised inner power structures:

There is a clear distribution of power in one network from the garment industry (undoubtedly characteristic for many co-operation relations between West and East European countries): The German clothing manufacturers occupy a central position of power, the Polish contract manufacturers only have very little power and an East German placement company is in a middling position of power.

In another network dealing with the manufacture of accordions there is a relative balance of power between the German end manufacturer and the Czech supplier of tuning-plates while the Czech producer of cases and carrier bags is in a weak position. This case is of interest insofar as it comprises an enterprise - in the shape of the Czech manufacturer of tuning-plates - that is able to combine 
relatively low wage costs with technological competence. Thus this manufacturer overcomes the dependent position in the power structure of the network structure which the Czech supplier of cases and carrier bags, for example, occupies and attains a position of interdependence with the German end producer. The situation in the two R\&D networks is characterised by a relative balance of power of the participating companies, one project coordinator, however, enjoys a prominent position of power.

At the beginning of the paper, we pointed out that we believe that as far as the co-ordination of network activities is concerned it makes sense to distinguish between social co-ordination media that are geared to the generation of "reliability" and the factual and temporal co-ordination of the individual activities in the network.

If one takes this differentiation into account when analysing the case studies, it appears that the global statements that are made time and again concerning the importance of specific individuals for SME-networks are, in fact, not wrong but that they conceal a more differentiated situation.

To begin with, it can be regarded as certain that individual persons play a central role especially in the initiation phase of networks. The mutual conclusion that the chemistry is right often stands right at the beginning of a co-operation or network relation between SMEs. It represents a kind of initial spark for the stepwise development of "reliability", but the process soon leaves the purely personal level and, for example, incorporates the interests and the resources of the involved companies. Nevertheless, a closer examination shows that the concrete role specific individuals play for the formation of networks differs markedly, depending on the given power constellations.

Companies from Central/Eastern Europe, which are primarily integrated into networks with West European enterprises due to their wage cost advantages, often existentially depend on the co-operation with the West European firms. Examples for this from our sample are the Polish companies that do job processing as well as the Czech producer of cases and carrier bags in the network "accordion". In these cases, the reliability is based on the knowledge of the West European enterprises that the Central/Eastern European companies will, in their own interest, do everything in their power to meet the demands of their partners and to prove reliable network actors. The familiarity between concrete persons thus does not primarily have the function of establishing and maintaining reliability but rather of making the factual and temporal coordination of all network activities more effective. In the case of the project-like organised R\&D -networks, the situation is quite different. Here it is already clear from the outset, that the expected economic advantages will not materialise immediately but only after a certain time. For the joint accomplishment of the R\&D activities, the companies inevitably have to open up to their partners to a certain degree, so that there is bound to be fear of an uncontrollable drain of 
know-how as well as of an unfair distribution of the costs and benefits of this mutual undertaking. Thus the enterprises do not only stand to win from the cooperation, they can definitely also lose out. There is a relative balance of power between the actors of the network. Apart from the common interest in the project' s success, there are also self-interests, so that there is a real danger of individual network participants behaving in an opportunistic way. Accordingly, no actor can take it for granted that the other actors will bring their resources into the network as agreed. Here it is incumbent on a concrete person continuously to see to a mutual transparency with regard to the intentions of the actors and to the distribution of burdens and profits of the collaboration as well as, early enough, to recognise and to rectify undesirable developments which jeopardise the "reliability". For this purpose, a person is needed who is regarded as competent by all the partners and who is not suspected of unfairly taking the side of one actor. Furthermore, he must have the corresponding instruments of power at his command in order to be able to prevent potential misconduct of individual network participants. In both networks this role is occupied by a project co-ordinator who has the necessary power due to his specific social capital. He disposes of the knowledge and contacts to guarantee the access to EU funds that are essential for the implementation of the development project. In the relations between the German accordion manufacturer and the Czech supplier of tuning-plates, which are characterised by a balance of power, the balancing of special interests and the reciprocal assurance of the intentions of the other company also play an important role for the maintenance of the "reliability". This "reliability" is moreover sustained by the long standing trusting relation between the Czech firm owner and the production manager of the German enterprise.

\section{Conclusions}

The concept of reliance proved to be a suitable means to analyse more thoroughly the links between the social embeddedness of SME networks and coordination media inside the networks. This became particularly clear in the case of networks comprising SMEs from Western Europe as well as firms from Central and Eastern Europe facing basic changes. On the basis of our findings, one can generally ascertain that the change in the network relations from a dominant utilisation of labour cost advantages to a form of co-operation that is geared more to making use of complementary competencies will also have consequences for the social co-ordination mechanisms of the networks. The more successful the Central/East European companies are at this transition, the stronger their position of power will be in relation to the West European partners. The latter can then no longer simply assume that the Central/East European companies will unconditionally subordinate themselves to all West European expectations within the scope of the co-operation but reliability will 
henceforth have to be ensured by means of an intensive communication process about the common interests of the network participants and by dint of a maximum transparency.

\section{References}

Angerer, J. (2000): Welche Bedeutung hat die Visegrad-Region für Sachsens Wirtschaft? in: ifo Dresden berichtet, 3, 14-18.

bfai (ed.) (2005): Tipps für die Praxis - Lohn- und Lohnnebenkosten, Köln.

Bartlett, C.A./Ghoshal, S. (1992): Managing Across Boarders, London: Century Business.

v. Behr, M./Hirsch-Kreinsen, H. (ed.) (1998): Globale Produktion und Industriearbeit. Arbeitsorganisation und Kooperation in Produktionsnetzwerken, Frankfurt/New York: Campus.

Bluhm, K. (2000): East-West Integration and the Changing German Production Regime: A Firm-Centered Approach, www.ces.fas.harvard.edu/publications/Bluhm53.pdf

Brücker, H./Schrettl, W. (1997): Entsteht eine neue wirtschaftliche Kluft in Europa? in: Aus Politik und Zeitgeschichte. Beilage zur Wochenzeitung Das Parlament, B 44-45, 17 26.

Eggers, T./Lay, G. (2003): Internationale Kooperationen. Verbreitung von Kooperationen mit ausländischen Unternehmen in der deutschen Investitionsgüterindustrie, in: HirschKreinsen, H./Wannöffel, M. (ed): Netzwerke kleiner Unternehmen, Berlin, 111-132.

Hirsch-Kreinsen, H. (2005): „Low-Tech-Industrien“: Innovationsfähigkeit und Entwicklungschancen, in: WSI-Mitteilungen, 58, 3, 144-150.

Hirsch-Kreinsen, H./Wannöffel, M. (2003): Netzwerke kleiner Unternehmen. Praktiken und Besonderheiten internationaler Zusammenarbeit, Berlin, edition sigma.

Kinkel, S./Lay, G./Maloca, S. (2004):Produktionsverlagerung ins Ausland und Rückverlagerung. Bericht zum Forschungsauftrag Nr. 8/04 an das Bundesministerium der Finanzen. Fraunhofer Institut für Systemtechnik und Innovationsforschung ISI, Karlsruhe.

Lungwitz, R.-E./Preusche, E. (2002): Kooperationsbeziehungen zwischen ostdeutschen kleinen und mittleren Unternehmen (KMU) und Unternehmen aus Polen und der Tschechischen Republik - Ergebnisse einer industriesoziologischen Untersuchung, in: osteuropa Wirtschaft, 47, 4, 338-353.

Müller-Jentsch, W. (2003): Organisationssoziologie. Eine Einführung, Frankfurt/Main, New York: Campus.

Ortmann, G. (2003): Organisation und Welterschließung: Dekonstruktionen, Wiesbaden, VSVerlag.

Peplak, T. (2002): Zur Lage der polnischen Textil- und Bekleidungsindustrie, $\mathrm{http}: / / \mathrm{www} \cdot$ fashionet.pl/?sid=view\&news $=257$

Pries, L. (1999): Auf dem Weg zu global operierenden Konzernen? BMW, Daimler-Benz und Volkswagen: die „Drei Großen“ der deutschen Automobilindustrie, München/Mering, Rainer Hampp Verlag. 
Schulten, T. (2004): Europäischer Tarifbericht des WSI-2003/2004; in: WSI-Mitteilungen 57, 7, 347-355.

Sauer, D./Döhl, V. (1994): Arbeit an der Kette. Systemische Rationalisierung unternehmensübergreifender Produktion, in: Soziale Welt, 45, 2, 197-215.

\section{Internet Sources}

OECD 2002: www.oecd.org/dataoecd/34/37/2771153.pdf

Observatory of European SME, Enterprise Survey 2003/ 5: http://europa.eu.int/comm/enterprise/enterprise_policy/analysis/observatory_en.htm 